\title{
Transport and development of embryos transferred to the oviducts and uteri of entire and ovariectomized ewes
}

\author{
N. W. Moore, B. G. Miller and M. N. Trappl* \\ Department of Animal Husbandry, University of Sydney, Camden, New South Wales 2570, \\ Australia
}

Summary. Embryos collected from donor ewes 2 or 3 days after oestrus were transferred synchronously to the oviducts or uterine horns of entire or ovariectomized ewes and 2-4 days after transfer the embryos were recovered by flushing the uteri and oviducts. Ovariectomized ewes were treated with all, or part, of a steroid hormone regimen designed to simulate ovarian secretion, in entire ewes of progesterone during the luteal phase before oestrus, of oestradiol around oestrus and of progesterone during the luteal phase after oestrus.

Irrespective of treatment regimen in ovariectomized ewes, only $\leqslant 50 \%$ of embryos transferred to the oviducts were recovered and the majority remained in the oviducts. Most of those remaining in the oviducts showed apparently normal development. In ewes on the complete regimen all of 3 embryos recovered from the uterus had developed normally, whereas none of 7 recovered from the uteri of ewes treated with only part of the regimen had developed normally. Most embryos transferred to the oviducts of entire ewes reached the uterus within 3 days of transfer and, irrespective of whether located in the uterus or oviducts, almost all had developed normally. Few 2-day embryos survived transfer to the uterus. When transfer was delayed to Day $3,70-80 \%$ of embryos recovered from entire ewes, and ovariectomized ewes given the full regimen, had developed normally, whereas only $20-30 \%$ of embryos recovered from ovariectomized ewes given part of the regimen developed normally.

Delayed transport of embryos from the oviducts to the uteri of ovariectomized ewes seemed to be due to deficiencies of the treatment regimen or residual effects of ovariectomy. However, the steroid hormone requirements for continued development in the oviducts were not critical, whereas requirements both of steroid hormone regimen and of time of transfer were critical for continued development in the uterus.

\section{Introduction}

The ovariectomized ewe has been used to study the steroid hormone requirements for early development of sheep embryos (Moore \& Rowson, 1959; Bindon, 1971 ; Trounson \& Moore, 1974), and Miller \& Moore (1976) have shown that a sequence of steroid hormone treatments simulating ovarian secretion of progesterone during the luteal phase of the oestrous cycle before oestrus, of oestradiol around the time of oestrus and of progesterone during the luteal phase after oestrus is necessary for the normal development of embryos transferred to the uterus of ovariectomized ewes a few days after oestrus induced by progesterone and oestradiol. When one or more components of the treatment regimen is omitted embryos fail to show normal development.

* Present address: Faculty of Medicine, University of Newcastle, Shortland, New South Wales 2308, Australia. 
However, little is known of the steroid hormone requirements for transport of embryos within the oviducts and uterus and for development of embryos within the oviducts. In this study embryos were recovered a few days after their transfer to the oviducts or uterine horns of entire or progesterone/oestradiol-treated ovariectomized ewes in an attempt to determine these requirements.

\section{Materials and Methods}

Entire and ovariectomized Merino ewes of 5-7 years of age were used in 2 experiments. The ovariectomized ewes had been ovariectomized at least 2 months before starting the experiments.

Experiment 1. Embryos collected from donor ewes 2 or 3 days after oestrus were transferred to the oviducts or uterine horns of entire or ovariectomized recipient ewes and 2 or 4 days after transfer the oviducts and uterine horns were flushed in vivo to recover transferred embryos. Dulbecco's phosphate buffer $(6-8 \mathrm{ml})$ was injected into each horn and expelled through the oviduct; the site of the embryos within the reproductive tract at the time of recovery was therefore unknown.

Donor ewes were treated with progestagen-impregnated intravaginal pessaries (Repromap: Upjohn Pty Ltd, Rydalmere, New South Wales, Australia) and PMSG to induce superovulation on predetermined dates. The entire ewes were treated only with intravaginal pessaries to control the time of oestrus which was detected with the aid of vasectomized rams. Ovariectomized ewes were treated with all, or part, of the steroid hormone schedule shown in Table 1. Three steroid hormone regimens were used : ewes in Group EPEP received all components of the schedule, those in Group EP were treated only from Day 15 and those in Group P were treated only from Day 18.

All transfers were synchronous, i.e. 2-day-old embryos were transferred on the 2nd, and 3-day embryos on the 3rd day after oestrus in ewes that exhibited oestrus or the equivalent day for those that did not. Seven to 15 embryos were transferred to each recipient and there were at least 4 ewes in

Table 1. Steroid hormone treatment $\left(P=\right.$ progesterone; $E_{2}=$ oestradiol $)$ of ovariectomized ewes (Exps 1 and 2)

\begin{tabular}{|c|c|c|c|c|}
\hline \multirow{2}{*}{$\begin{array}{c}\text { Day of } \\
\text { experiment }\end{array}$} & \multirow{2}{*}{$\underset{\text { (h) }}{\text { Time }}$} & \multirow[b]{2}{*}{ Hormone treatment ${ }^{*}$} & \multicolumn{2}{|c|}{ Procedure or event } \\
\hline & & & Exp. 1 & Exp. 2 \\
\hline 0 & $08: 00$ & $25 \mu \mathrm{g} \mathrm{E}_{2}$ & & \\
\hline $3-14$ & $08: 00$ & $12 \mathrm{mg} \mathrm{P}$ & & \\
\hline 15 & $\begin{array}{l}16: 00 \\
24: 00\end{array}$ & $\begin{array}{l}3.5 \mu \mathrm{g} \mathrm{E} \\
7.0 \mu \mathrm{g} \mathrm{E}\end{array}$ & & \\
\hline 16 & $08: 00$ & $14.0 \mu \mathrm{g} \mathrm{E}_{2}$ & & \\
\hline & $16: 00$ & $7.0 \mu \mathrm{g} \mathrm{E}_{2}$ & & \\
\hline & $24: 00$ & $3.5 \mu \mathrm{g} \mathrm{E}$ & Oestrus & Oestrus \\
\hline 17 & & - & Oestrus & Oestrus \\
\hline 18 & $\begin{array}{l}06: 00 \\
18: 00\end{array}$ & $\begin{array}{l}0.50 \mathrm{mg} \mathrm{P} \\
0.625 \mathrm{mg} \mathrm{P}\end{array}$ & & \\
\hline 19 & $06: 00$ & $0.75 \mathrm{mg} \mathrm{P}$ & Transfer of embryos & Transfer of embryos \\
\hline & $18: 00$ & $1.00 \mathrm{mg} \mathrm{P}$ & & \\
\hline 20 & $06: 00$ & $1.25 \mathrm{mg} \mathrm{P}$ & Transfer of embryos & \\
\hline & $18: 00$ & $1.50 \mathrm{mg} \mathrm{P}$ & & \\
\hline 21 & $06: 00$ & $2.00 \mathrm{mg} \mathrm{P}$ & Recovery of embryos & \\
\hline & $18: 00$ & $2.50 \mathrm{mg} \mathrm{P}$ & & \\
\hline 22 & $06: 00$ & $3.00 \mathrm{mg} \mathrm{P}$ & Recovery of embryos & Recovery of embryos \\
\hline & $18: 00$ & $4.00 \mathrm{mg} \mathrm{P}$ & & \\
\hline 23 & $06: 00$ & $5 \cdot 00 \mathrm{mg} \mathrm{P}$ & Recovery of embryos & \\
\hline & $18: 00$ & $6.00 \mathrm{mg} \mathrm{P}$ & & \\
\hline 24 & $06: 00$ & $8.00 \mathrm{mg} \mathrm{P}$ & Recovery of embryos & \\
\hline
\end{tabular}

* Group EPEP ewes were treated from Day 0, Group EP ewes from Day 15 and Group P ewes from Day 18. 
each treatment group. The number of embryos transferred to individual ewes was divided as equally as possible between the 2 oviducts or uterine horns. Transfers to the oviducts were made using a smooth-ended pipette inserted via the fimbria $2-3 \mathrm{~cm}$ into the oviducts. Uterine transfers were carried out using a sharp-ended pipette stabbed through the wall of the uterus and embryos were deposited into the lumen some $3-4 \mathrm{~cm}$ from the utero-tubal junction.

Experiment 2. Embryos collected from donors on the 2 nd day after oestrus were transferred synchronously to the oviducts of entire or ovariectomized ewes which were slaughtered 3 days after transfer. Immediately after slaughter, the oviducts were dissected out and the uterine horns and oviducts were flushed separately. Otherwise, the procedures used and treatments involved were the same as those of Exp. 1.

Assessment of embryos. To be classed as normal, embryos recovered from recipients were required to have reached a stage of development comparable to that of embryos recovered from entire ewes at known times after oestrus. Experience in this laboratory has shown these stages to be : $8-20$ cells at 4 days after oestrus, 12 cells to early morula at 5 days, morula to early blastocyst at 6 days and expanded blastocyst at 7 days after oestrus. Embryos that were not at these stages of development or that showed gross cellular abnormalities were classed as abnormal.

\section{Experiment 1}

\section{Results}

No transfers were made to the oviducts of entire ewes (Table 2) and for this reason 2 series of $\chi^{2}$ tests were carried out. One series was restricted to data for ovariectomized ewes, the other included data for entire and ovariectomized ewes but was restricted to uterine transfers.

Table 2. Proportions of embryos recovered following transfer to the oviducts or uterine horns of entire and ovariectomized ewes (Exp. 1)

\begin{tabular}{cccccccc}
\hline \multirow{2}{*}{$\begin{array}{c}\text { Time of } \\
\text { transfer* } \\
\text { (days) }\end{array}$} & $\begin{array}{c}\text { Site of } \\
\text { transfer }\end{array}$ & $\begin{array}{c}\text { Time of } \\
\text { recovery } \\
\text { (days) }\end{array}$ & $\begin{array}{c}\text { Control } \\
\text { (entire) }\end{array}$ & $\begin{array}{c}\text { Group } \\
\text { EPEP }\end{array}$ & $\begin{array}{c}\text { Group } \\
\text { EP }\end{array}$ & $\begin{array}{c}\text { Group } \\
\text { P }\end{array}$ & Total \\
\hline \multirow{2}{*}{2} & Oviduct & 2 & - & $10 / 26$ & $11 / 26$ & $9 / 25$ & $30 / 77$ \\
& Oviduct & 4 & - & $7 / 24$ & $7 / 26$ & $4 / 15$ & $18 / 65$ \\
& & Total & - & $17 / 50$ & $18 / 52$ & $13 / 40$ & $48 / 142$ \\
\hline 3 & Oviduct & 2 & - & $9 / 14$ & $8 / 14$ & $7 / 15$ & $24 / 43$ \\
& Oviduct & 4 & - & $6 / 13$ & $6 / 14$ & $8 / 15$ & $20 / 42$ \\
& & Total & - & $15 / 27$ & $14 / 28$ & $15 / 30$ & $44 / 85$ \\
\hline 2 & Uterus & 2 & $20 / 26$ & $11 / 17$ & $8 / 19$ & $2 / 10$ & $41 / 72$ \\
& Uterus & 4 & $22 / 33$ & $8 / 16$ & $17 / 24$ & $8 / 22$ & $55 / 95$ \\
& & Total & $42 / 59$ & $19 / 33$ & $25 / 43$ & $10 / 32$ & $96 / 167$ \\
\hline 3 & Uterus & 2 & $29 / 40$ & $12 / 12$ & $9 / 17$ & $5 / 11$ & $55 / 80$ \\
& Uterus & 4 & $36 / 41$ & $15 / 17$ & $11 / 18$ & $4 / 18$ & $66 / 94$ \\
& & Total & $65 / 81$ & $27 / 29$ & $20 / 35$ & $9 / 29$ & $121 / 174$ \\
\hline
\end{tabular}

* Days after oestrus or equivalent stage of treatment in ovariectomized ewes in Group P.

$\dagger$ Days after transfer. Embryos were recovered by flushing the uterus and oviducts together.

Embryos recovered. There were effects of time of transfer, site of transfer and treatment on the proportion of embryos recovered from ovariectomized ewes together with several significant interactions, but there was no effect of time of recovery (Table 3). The recovery rate in Group EP was depressed $(77 / 178(49 \%)$ compared with $78 / 139(56 \%)$ for Group EPEP) and the value for Group P 
was even lower $(47 / 131,36 \%)$. However, the effect of treatment was modified by both site and time of transfer. When embryos were transferred to the oviducts treatment regimen had little effect upon the proportion of embryos recovered, whereas with uterine transfers there was a marked effect of treatment: $46 / 62(74 \%), 45 / 78(58 \%)$ and $19 / 61(31 \%)$ of embryos were recovered from ewes in Groups EPEP, EP and P respectively. There was little effect of treatment on the recovery of embryos transferred 2 days after oestrus, but this was not so of 3-day transfers (Group EPEP 42/56 $(75 \%)$; Group EP 34/63 (54\%); Group P 24/59 (41\%)). Of 29 embryos transferred to the uterus of Group EPEP ewes on the 3rd day after oestrus, $27(93 \%)$ were recovered, and this to a large degree was responsible for the significant time of transfer $\times$ site of transfer $\times$ treatment interaction.

Table 3. Table of $\chi^{2}$ for the proportions of transferred embryos recovered in Exp. 1

\begin{tabular}{|c|c|c|c|c|c|c|}
\hline \multirow[b]{2}{*}{ Source of deviation } & \multicolumn{3}{|c|}{$\begin{array}{c}\text { Ovariectomized ewes } \\
\text { (Groups EPEP, EP and P) }\end{array}$} & \multicolumn{3}{|c|}{$\begin{array}{c}\text { Uterine transfers } \\
\text { (entire and ovariectomized ewes) }\end{array}$} \\
\hline & $\chi^{2}$ & d.f. & $P$ & $\chi^{2}$ & d.f. & $P$ \\
\hline Time of transfer & $9 \cdot 84$ & 1 & $<0.01$ & $5 \cdot 34$ & 1 & $<0.05$ \\
\hline Site of transfer & $8 \cdot 61$ & 1 & $<0.01$ & - & - & - \\
\hline Time of recovery & 0.53 & 1 & NS & 0 & 1 & NS \\
\hline Treatment & $11 \cdot 30$ & 2 & $<0.01$ & $41 \cdot 87$ & 3 & $<0.001$ \\
\hline Significant interactions & & & & & & Nil \\
\hline Time of transfer $\times$ treatment & $5 \cdot 72$ & 2 & $\approx 0.05$ & & & \\
\hline Site $\times$ treatment & $12 \cdot 06$ & 2 & $<0.01$ & & & \\
\hline Time of transfer $\times$ site $\times$ treatment & 11.97 & 2 & $<0.01$ & & & \\
\hline
\end{tabular}

Tests on the data on uterine transfers for entire and ovariectomized ewes showed effects of time of transfer and treatment on the proportion of embryos recovered (Table 3 ). The proportion of embryos recovered after 3-day transfers exceeded that for 2-day transfers $(121 / 174(70 \%)$ and $96 / 167(54 \%)$, respectively). There was no difference between recovery rates from entire ewes and those in Group EPEP $(107 / 140(76 \%)$ and $46 / 62(74 \%)$, respectively). However, the recovery rate was reduced in Groups EP $(45 / 78,58 \%)$ and P $(19 / 61,31 \%)$.

Development of embryos. Within ovariectomized ewes there were effects of time of transfer, treatment, site of transfer and time of recovery of embryos on the proportion of recovered embryos which showed normal development (Tables 4 \& 5). Overall, the proportion of embryos classed as normal was influenced by treatment (Group EPEP 55/78 (71\%); Group EP 36/77 (47\%); Group P $19 / 47(40 \%)$ ), but the effect of treatment regimen was modified by time of transfer and site of transfer. When transfers were made to the oviducts 2 or 3 days after oestrus, treatment regimen had little effect upon development. Following 3-day uterine transfers, a high proportion (22/27) of embryos recovered from Group EPEP ewes were classed as normal, whereas only 6 of 29 embryos recovered from ovariectomized ewes in the other treatment groups were classed as normal. Irrespective of treatment regimen very few embryos recovered after 2-day uterine transfers showed normal development, and as the time elapsing between transfer and recovery increased from 2 to 4 days so the proportion classed as normal decreased (11/21 compared with $1 / 33$ ).

When data on uterine transfers were considered (Table 5), effects of time of transfer, treatment and time of recovery together with a significant interaction between time of transfer and time of recovery became apparent. Following 2-day transfers the proportion of recovered embryos classed as normal was low, irrespective of whether recipients were entire or ovariectomized. The proportion classed as normal decreased as the time elapsing between transfer and recovery increased from 2 to 4 days.

With 3-day transfers to the uterus of ovariectomized ewes in Groups EP and P, the proportion of recovered embryos classed as normal was low and there was an effect of time of recovery, whereas a high proportion of embryos recovered from entire ewes and Group EPEP ovariectomized ewes were classed as normal and there was little or no effect of time of recovery. 
Table 4. Proportions of recovered embryos classed as normal following their transfer to the oviducts and uterine horns of entire and ovariectomized ewes (Exp. 1)

\begin{tabular}{cccccccc}
\hline & & \multicolumn{5}{c}{ Treatment } \\
\cline { 5 - 7 } $\begin{array}{c}\text { Time of } \\
\text { transfer* } \\
\text { (days) }\end{array}$ & $\begin{array}{c}\text { Site of } \\
\text { transfer }\end{array}$ & $\begin{array}{c}\text { Time of } \\
\text { recovery } \\
\text { (days) }\end{array}$ & $\begin{array}{c}\text { Control } \\
\text { (entire) }\end{array}$ & $\begin{array}{c}\text { Group } \\
\text { EPEP }\end{array}$ & $\begin{array}{c}\text { Group } \\
\text { EP }\end{array}$ & $\begin{array}{c}\text { Group } \\
\text { P }\end{array}$ & Total \\
\hline 2 & Oviduct & 2 & - & $9 / 10$ & $10 / 11$ & $8 / 9$ & $27 / 30$ \\
& Oviduct & 4 & - & $4 / 7$ & $4 / 7$ & $1 / 4$ & $9 / 18$ \\
& & Total & - & $13 / 17$ & $14 / 18$ & $9 / 13$ & $36 / 48$ \\
\hline 3 & Oviduct & 2 & - & $9 / 9$ & $8 / 8$ & $3 / 7$ & $20 / 24$ \\
& Oviduct & 4 & - & $5 / 6$ & $4 / 6$ & $5 / 8$ & $14 / 20$ \\
& & Total & - & $14 / 15$ & $12 / 14$ & $8 / 15$ & $34 / 44$ \\
\hline 2 & Uterus & 2 & $19 / 20$ & $5 / 11$ & $5 / 8$ & $1 / 2$ & $30 / 41$ \\
& Uterus & 4 & $4 / 22$ & $1 / 8$ & $0 / 17$ & $0 / 8$ & $5 / 55$ \\
& & Total & $23 / 42$ & $6 / 19$ & $5 / 25$ & $1 / 10$ & $35 / 96$ \\
\hline 3 & Uterus & 2 & $25 / 29$ & $11 / 12$ & $5 / 9$ & $1 / 5$ & $42 / 55$ \\
& Uterus & 4 & $19 / 36$ & $11 / 15$ & $0 / 11$ & $0 / 4$ & $30 / 66$ \\
& & Total & $44 / 65$ & $22 / 27$ & $5 / 20$ & $1 / 9$ & $72 / 121$ \\
\hline
\end{tabular}

* Days after oestrus or equivalent stage of treatment in ovariectomized ewes in Group P.

$\dagger$ Days after transfer. Embryos were recovered by flushing the uterus and oviducts together.

Table 5. Table of $\chi^{2}$ for the proportions of normal embryos recovered in Exp. 1

\begin{tabular}{|c|c|c|c|c|c|c|}
\hline \multirow[b]{2}{*}{ Source of deviation } & \multicolumn{3}{|c|}{$\begin{array}{c}\text { Ovariectomized ewes } \\
\text { (Groups EPEP, EP and P) }\end{array}$} & \multicolumn{3}{|c|}{$\begin{array}{c}\text { Uterine transfers } \\
\text { (entire and ovariectomized ewes) }\end{array}$} \\
\hline & $\chi^{2}$ & d.f. & $P$ & $\chi^{2}$ & d.f. & $P$ \\
\hline Time of transfer & 4.55 & 1 & $<0.05$ & $11 \cdot 36$ & 1 & $<0.001$ \\
\hline Site of transfer & 31.86 & 1 & $<0.001$ & - & & - \\
\hline Time of recovery & 31.92 & 1 & $<0.001$ & $45 \cdot 46$ & 1 & $<0.001$ \\
\hline Treatment & 13.65 & 2 & $<0 \cdot 01$ & $34 \cdot 68$ & 3 & $<0.001$ \\
\hline \multicolumn{7}{|l|}{ Significant interactions } \\
\hline Time of transfer $\times$ time of recovery & 4.85 & 1 & $<0.05$ & 4.59 & 1 & $<0.05$ \\
\hline Site $\times$ time of recovery & $7 \cdot 79$ & 1 & $<0.01$ & & & \\
\hline Site $\times$ treatment & $10 \cdot 13$ & 2 & $<0.01$ & & & \\
\hline Time of transfer $\times$ site $\times$ time of recovery & 18.71 & 1 & $<0.001$ & & & \\
\hline Time of transfer $\times$ site $\times$ treatment & 18.69 & 2 & $<0.001$ & & & \\
\hline
\end{tabular}

\section{Experiment 2}

There was a major difference between the proportions of embryos recovered from entire and ovariectomized ewes $\left(32 / 45\right.$ and $42 / 124 ; \chi_{1}^{2}=18.60 ; P<0.001$; Table 6), but within ovariectomized ewes there was no effect of treatment regimen on recovery rates $\left(\chi_{2}^{2}=0.63\right)$. In entire ewes most embryos were found in the uterus $(23 / 32,72 \%)$, whereas most of the embryos recovered from ovariectomized ewes were still located in the oviducts $(32 / 42,76 \%)$, but there was no effect of treatment on the location of embryos in ovariectomized ewes.

Irrespective of location, the majority of embryos recovered from entire ewes were classed as normal, as were most of the embryos recovered from the oviducts of ovariectomized ewes. However, there was a suggestion of an effect of treatment on the development of embryos recovered from the uterus of ovariectomized ewes. The 3 embryos recovered from the uterus in Group EPEP 
Table 6. Proportions of embryos recovered from the uterus and oviducts and proportion classed as normal following transfer to the oviducts of entire and ovariectomized ewes (Exp. 2)

\begin{tabular}{|c|c|c|c|c|c|c|}
\hline \multirow[b]{2}{*}{ Treatment } & \multicolumn{3}{|c|}{ Recovered } & \multicolumn{3}{|c|}{ Classed as normal } \\
\hline & Oviducts & Uterus & Total & Oviducts & Uterus & Total \\
\hline $\begin{array}{l}\text { Control } \\
\text { (entire) }\end{array}$ & $9 / 45$ & $23 / 45$ & $32 / 45$ & $9 / 9$ & $22 / 23$ & $31 / 32$ \\
\hline Group EPEP & $9 / 41$ & $3 / 41$ & $12 / 41$ & $9 / 9$ & $3 / 3$ & $12 / 12$ \\
\hline Group EP & $8 / 40$ & $6 / 40$ & $14 / 40$ & $7 / 8$ & $0 / 6$ & $7 / 14$ \\
\hline Group P & $15 / 43$ & $1 / 43$ & $16 / 43$ & $13 / 15$ & $0 / 1$ & $13 / 16$ \\
\hline Total & $41 / 169$ & $33 / 169$ & $74 / 169$ & $38 / 41$ & $25 / 33$ & $63 / 74$ \\
\hline
\end{tabular}

Embryos were transferred on the 2nd day after oestrus or equivalent stage of treatment in ovariectomized ewes which did not show oestrus, and recovered 3 days after transfer from oviducts and uteri flushed separately.

were classed as normal, whereas none of 7 located in the uterus of ewes in Groups EP and P were classed as normal.

In both experiments all embryos classed as abnormal were retarded and some had lost their cellular integrity.

\section{Discussion}

Overall, only $30-50 \%$ of embryos were recovered after transfer to the oviducts of the ovariectomized ewes, whereas almost $70 \%$ were recovered from entire ewes following transfer to the oviducts. There was no effect in ovariectomized ewes of deletion of one or more components of the steroid hormone treatment on recovery of embryos. Clearly, transport of embryos within the oviducts of all ovariectomized ewes was faulty and it would seem that loss of embryos through the fimbria into the abdominal cavity is a more likely reason for low recovery rates than is rapid transport to, and through, the uterus and loss through the cervix. In Exp. 2 in which the uterine horns and oviducts were flushed separately most of the embryos recovered from ovariectomized ewes were located in the oviducts. Substantial loss occurred after uterine transfers, but this was observed only in the ewes in Group P, i.e. treated with progesterone from Day 18 only. In ovariectomized ewes in Groups EPEP and EP, i.e. full hormone treatment and treatment from Day 15 , recovery rates after uterine transfers were similar to those achieved with entire ewes. Omission of the oestrogen injections on Days 15-17 in Group P ewes can therefore be implicated in loss from the uterus, but not from the oviducts. Two explanations for faulty transport following transfer to the oviduct would seem possible. First, the surgical procedures of ovariectomy may influence the subsequent ability of the oviduct to allow transport to the uterus or prevent escape of embryos through the fimbria. Second, the steroid hormone regimen may be deficient. Ovarian secretion of oestradiol by the ewe at about the 3rd-4th day after oestrus is well documented (Cox, Mattner $\&$ Thorburn, 1971; Mattner \& Braden, 1972) and at this time embryos would normally be entering the uterus. The secretion of oestrogen after oestrus has been implicated in tubal transport of eggs in a number of species (see Adams, 1976). Although luteal-phase oestrogen secretion does not appear to be directly involved in the survival and development of embryos within the uterus of the ewe (Miller, Moore, Murphy \& Stone, 1977), it may well, as suggested by Holst \& Braden (1972), affect the transport of embryos through the oviduct.

Failure of embryos to enter the uterus did not inhibit their development and in fact steroid hormone regimens used for Groups EP and P, which will not support normal development of embryos transferred to the uteri of ovariectomized ewes (Miller \& Moore, 1976), 'were associated with normal development of most of those embryos that remained in the oviducts. Of the few 
embryos that reached the uterus in ewes in these groups none was classed as normal. Clearly, the steroid hormone requirements for development within the oviducts are not as critical as those for the uterus. Continued normal development of sheep embryos in the rabbit oviduct (Averill, Adams \& Rowson, 1955) is further evidence for perhaps a rather passive role of the oviduct in the development of early embryos. The same is not true of the uterus. There are critical time and steroid hormone requirements which must be satisfied if development is to proceed. The failure of normal development of embryos transferred on the 2 nd day after oestrus to the uterus of entire ewes and ovariectomized ewes on a treatment regimen which has been shown to support development of embryos placed in the uterus 1 or 2 days later (Miller \& Moore, 1976) provides further evidence of the hostility of the uterus to embryos that reach it, or are placed in it, prematurely (Robinson, 1951 ; Moore \& Shelton, 1964). The uterus expresses its hostility rapidly as many of the embryos recovered only 2 days after transfer were retarded, and by 4 days after transfer almost all were retarded and classed as abnormal.

We thank the Australian Wool Corporation for financial support and Mrs G. Saunders, Mr J. Ellsmore and Mr C. Stimson for skilled technical assistance.

\section{References}

Adams, C.E. (1976) Egg survival relative to maternal endocrine status. In Ovum Transport and Fertility Regulation, pp. 425-440. Eds M. J. K. Harper, C. J. Pauerstein, C. E. Adams, E. M. Coutinho, H. B. Croxatto \& D. M. Paton. Scriptor, Copenhagen.

Averill, R.L.W., Adams, C.E. \& Rowson, L.E.A. (1955) Transfer of mammalian ova between species. Nature, Lond. 176, 167.

Bindon, B.M. (1971) The role of progesterone in implantation in sheep. Aust. J. biol. Sci. 24, 149-158.

Cox, R.I., Mattner, P.E. \& Thorburn, G.D. (1971) Changes in ovarian secretion of oestradiol-17 $\beta$ around oestrus in the sheep. J. Endocr. 49, 345-346.

Holst, P.J. \& Braden, A.W.A. (1972) Ovum transport in the ewe. Aust. J. biol. Sci. 25, 167-173.

Mattner, P.E. \& Braden, A.W.H. (1972) Secretion of oestradiol-17 $\beta$ by the ovine ovary during the luteal phase of the oestrous cycle in relation to ovulation. $J$. Reprod. Fert. 28, 136-137.

Miller, B.G. \& Moore, N.W. (1976) Effects of progesterone and oestradiol on RNA and protein metabolism in the genital tract and on survival of embryos in the ovariectomized ewe. Aust. J. biol. Sci. 29, 563-573.

Miller, B.G., Moore, N.W., Murphy, L. \& Stone, G.M. (1977) Early pregnancy in the ewe: effects of oestradiol and progesterone on uterine metabolism and embryo survival. Aust. J. biol. Sci. 30, 279-288.

Moore, N.W. \& Rowson, L.E.A. (1959) Maintenance of pregnancy in ovariectomized ewes by means of progesterone. Nature, Lond. 184, 1410.

Moore, N.W. \& Shelton, J.N. (1964) Egg transfer in sheep. Effect of degree of synchronization between donor and recipient, age of egg and site of transfer on survival of transferred eggs. J. Reprod. Fert. 7, 145152.

Robinson, T.J. (1951) The control of fertility in sheep. The augmentation of fertility by gonadotrophin treatment of the ewe in the normal breeding season. $J$. agric. Sci., Camb. 41, 6-63.

Trounson, A.O. \& Moore, N.W. (1974) Effects of progesterone and cestrogen on the survival and development of fertilized ova in the ovariectomized ewe. Aust. J. biol. Sci. 27, 511-517.

Received 31 August 1982 